\title{
Freeze-thaw durability of cement-based geothermal grouting materials
}

\author{
Borinaga-Treviño, Roque ; Pascual-Muñoz, Pablo ; Calzada-Pérez, Miguel Ángela ; Castro-Fresno, Daniel ${ }^{a}$ \\ ${ }^{a}$ Department of Transports, Projects and Processes Technology, University of Cantabria, Spain.
}

\begin{abstract}
The required vertical closed loop geothermal heat exchanger size highly depends on the peak demand of the building when no complementary heat source is included. If grouting materials were able to resist freezing temperatures, a mean-demand designed geothermal heat exchanger would be sufficient to fulfill the energy requirements of the building, either preventing the oversizing of the geothermal heat exchanger or the necessity of a hybrid system and therefore saving their associated cost. This paper analyzes the freeze-thaw durability of five cement based geothermal grouting mortars. One was a neat cement $(\mathrm{N})$ and the rest contained either Limestone sand (L), silica sand (S), electric arc furnace slag (EAF) or Construction and demolition Waste (CDW). Mortars were either exposed up to 25 freeze-thaw cycles or to continuous water curing to analyze the influence of both treatments on the volumetric water content, flexural, compressive and pipe to mortar adherence loads and on the thermal conductivity of the resulting mortars. Results show no significant damage due to the freeze-thaw cycles applied to all the mortars but the Neat cement, probably due to the non-saturation of the core of the probes. Although neat cement presented no flexural resistance to freeze-thaw cycles and the probes were severely damaged, no influence was observed on the thermal conductivity of the core material, denoting that any loss of efficiency of a geothermal heat exchanger must be due to the increment of the contact thermal resistance between the pipe and grout or the creation of new contact resistances in the fractures of the grout itself.
\end{abstract}

\section{KEYWORDS}

Freeze; thaw; durability; geothermal grout; mortar; borehole; thermal conductivity;

\section{INTRODUCTION}

Geothermal heat pump systems take advantage of the year-round constant ground temperature to obtain higher efficiencies than any other system, as stated by the Environmental Protection Agency [1]. Instead of using ambient air as a heat source or sink, closed geothermal heat pump systems (CGHP) use a heat carrying fluid which flows through a buried pipe circuit and exchanges heat indirectly with the ground. When vertical heat exchangers are used, the closed pipe circuit is introduced into a vertical borehole reaching depths of up to $200 \mathrm{~m}$. To protect the heat exchanger pipes from the possible collapse of the borehole walls, borehole is filled with a grouting material. This material must present good mechanical and thermal properties to transfer heat from the pipes to the ground or vice versa and to ensure the borehole wall stability.

Apart from the base demand, the design of a geothermal system is highly dependent on the peak demand of the installation, leading to highly over-dimensioned geothermal systems. Since the construction of a ground heat exchanger is much more expensive than any other conventional HVAC system, geothermal 
installations are normally designed for base demand, while peak demand is usually covered by more economic alternatives (solar thermal energy, boilers, cooling towers, etc.). It would be possible to cover short-term peak demands if the heat carrier fluid was allowed to reach temperatures below water freezing point $(\mathrm{O} O \mathrm{C})$. However, freezing the grout might lead to a permanent reduction of the system efficiency. If grout is designed to resist such freeze-thaw cycles, there would be some benefits that could be exploited. The water high latent heat of fusion and the higher thermal conductivity of the ice over the water, 2.22 $\mathrm{W} /(\mathrm{m} \mathrm{K})$ over $0.566 \mathrm{~W} /(\mathrm{m} \mathrm{K})$ at $0{ }^{\circ} \mathrm{C}[2]$ should enhance grout thermal conductivity, reducing the borehole thermal resistance and hence improving the system's overall efficiency. This efficiency improvement could permit to satisfy peak demand of the system with a mean demand designed geothermal system, reducing its overall construction cost.

Influence of the freeze-thaw cycles in cement-based materials such as concrete or mortar has been studied by many authors, as it is summarized in Table 1. The type and number of freeze-thaw cycles as well as the tested properties depend on the type of exposure of the material. However, there is little bibliography on the effect of freeze-thaw cycles on the geothermal grouting materials. Allan et al. [3] evaluated the freezethaw durability of silica sand-based geothermal mortars by using the ultrasonic velocity test and also checking the pipe to mortar bond integrity, concluding that no significant damage was observed after 300 cycles. Recently, Park et al. [4] analyzed the effect of the freeze-thaw cycles on the compressive strength of a cement-based geothermal mortar concluding that its value is reduced as the number of cycles increased. The main goal of this paper is to analyze the damage caused by the freeze-thaw cycles in the physical, mechanical and thermal properties of geothermal cement-based grouting materials. As each mortar used in the analysis contained a different aggregate type, its influence on the freeze-thaw durability is also determined.

Table 1. Previous studies of the damage caused by freeze-thaw cycles in concretes and mortars.

\begin{tabular}{|c|c|c|c|c|c|c|c|c|c|c|c|}
\hline \multirow[t]{2}{*}{ Material } & \multirow[t]{2}{*}{ Reference } & \multicolumn{3}{|c|}{ Freezing cycle } & \multicolumn{3}{|c|}{ Thawing cycle } & \multirow[t]{2}{*}{ \#Cycles } & \multirow[t]{2}{*}{ Standard } & \multirow[t]{2}{*}{ Tested property } & \multirow[t]{2}{*}{ Conclusion } \\
\hline & & $\mathrm{T}\left({ }^{\circ} \mathrm{C}\right)$ & $t(h)$ & Ambience & $\mathrm{T}\left({ }^{\circ} \mathrm{C}\right)$ & $t(h)$ & Ambience & & & & \\
\hline $\begin{array}{l}\text { Concrete and } \\
\text { (FRP) }\end{array}$ & $\begin{array}{c}\text { Quiao and } X u \\
\text { [5] }\end{array}$ & -18 & 16 & Air & 22 & 8 & Air & $50 / 100$ & ND & $\begin{array}{l}\text { Bond } 3 \text { point } \\
\text { flexural strength }\end{array}$ & $\begin{array}{l}\text { Significant } \\
\text { damage }\end{array}$ \\
\hline $\begin{array}{c}\text { Concrete and } \\
\text { CFRP }\end{array}$ & $\begin{array}{l}\text { Colombi et } \\
\text { al. [6] }\end{array}$ & -18 & 5 & ND & 4 & 5 & ND & $100 / 200$ & $\begin{array}{l}\text { ASTM } \\
\text { C666 }\end{array}$ & $\begin{array}{c}\text { Pull out } \\
\text { debonding test }\end{array}$ & $\begin{array}{l}\text { No significant } \\
\text { damage }\end{array}$ \\
\hline $\begin{array}{l}\text { Concrete and } \\
\text { CFRP }\end{array}$ & $\begin{array}{l}\text { Green et al. } \\
\text { [7] }\end{array}$ & -18 & & & 15 & 8 & Water & 300 & $\begin{array}{l}\text { ASTM } \\
\text { C310 }\end{array}$ & Bond strength & $\begin{array}{c}\text { No significant } \\
\text { damage }\end{array}$ \\
\hline $\begin{array}{l}\text { Reinforced } \\
\text { concrete }\end{array}$ & Hanjari et & & & $\begin{array}{l}\text { Water at } \\
\text { surface }\end{array}$ & 20 & 12 & $\begin{array}{l}\text { Water at } \\
\text { surface }\end{array}$ & $*$ & $\begin{array}{c}\text { RILEM TC } \\
176-I D C\end{array}$ & $\begin{array}{l}\text { Compressive, } \\
\text { bond and } \\
\text { splitting } \\
\text { strengths, etc. }\end{array}$ & $\begin{array}{l}\text { Significant } \\
\text { reduction of all } \\
\text { parameter. }\end{array}$ \\
\hline $\begin{array}{l}\text { EAF and } \\
\text { limestone- } \\
\text { based } \\
\text { concretes }\end{array}$ & Manso et al. & -17 & 18 & Air & 4 & 6 & Water & 25 & ND & $\begin{array}{l}\text { Weight and } \\
\text { compressive } \\
\text { strength }\end{array}$ & $\begin{array}{l}\text { Durability of } \\
\text { EAF concrete is } \\
\text { similar to that } \\
\text { of standard } \\
\text { concrete }\end{array}$ \\
\hline $\begin{array}{l}\text { Masonry } \\
\text { mortar and } \\
\text { stone }\end{array}$ & $\begin{array}{l}\text { Maurenbrec } \\
\text { her et al. [10] }\end{array}$ & $\begin{array}{l}-12 /- \\
20\end{array}$ & $8 / 8$ & Air/Air & 15 & 8 & $\begin{array}{l}\text { Water } \\
\text { sprayed }\end{array}$ & $24 / 60$ & ND & Bond strength & $\begin{array}{c}\text { Bond failure is } \\
\text { general after } 60 \\
\text { cycles }\end{array}$ \\
\hline $\begin{array}{l}\text { Cement } \\
\text { mortar }\end{array}$ & $\begin{array}{c}\text { Cao et al. } \\
\text { [11] }\end{array}$ & -20 & 0.66 & Air & 50 & 0.66 & Air & ND & ND & Electric resistivity & $\begin{array}{l}\text { Progressive } \\
\text { damage during } \\
\text { cool cycle due } \\
\text { to the thermal } \\
\text { contraction }\end{array}$ \\
\hline $\begin{array}{l}\text { Silica sand - } \\
\text { based mortar }\end{array}$ & $\begin{array}{c}\text { Allan et al. } \\
{[3]}\end{array}$ & -18 & 5 & Air & 4 & 5 & Air & 300 & $\begin{array}{l}\text { ASTM } \\
\text { C666 }\end{array}$ & $\begin{array}{l}\text { Ultrasonic pulse } \\
\text { velocity and } \\
\text { bond integrity }\end{array}$ & $\begin{array}{c}\text { No significant } \\
\text { damage }\end{array}$ \\
\hline $\begin{array}{l}\text { Cement-based } \\
\text { geothermal } \\
\text { grout }\end{array}$ & Park et al. [4] & -5 & 240 & $\mathrm{HCC}$ & 50 & 120 & $\mathrm{HCC}$ & 1 & ND & $\begin{array}{l}\text { Compressive } \\
\text { strength, } \\
\text { thermal } \\
\text { conductivity, } \\
\text { hydraulic } \\
\text { conductivity }\end{array}$ & $\begin{array}{l}\text { Reduction of } \\
\text { compressive } \\
\text { strength with } \\
\text { the freeze-thaw } \\
\text { cycle }\end{array}$ \\
\hline
\end{tabular}

FRP: Fiber reinforced polymer; CFRP: Carbon fiber reinforced polymer; ND: Not defined by the author; HCC: humidity controlled chamber: unsaturated conditions

* Process was finished when compressive strength was reduced in $25 \%$ and $50 \%$, respectively

2. METHODOLOGY 


\subsection{Materials and mix proportions}

Aggregate properties, mix proportion design and initial characterization of the five different mix proportions used in this paper have been performed in a previous release [12]. Each mortar is made of cement (c), water (w), superplasticizer (sp) and a different aggregate type as basic constituent. Neat cement grout $(\mathrm{N})$ has been used as reference material to represent the aggregate absence.

Most of the grouts used at present are thermally improved by the addition of quartz or siliceous aggregates, but any other alternative aggregate has been studied up to date. The use of alternative local aggregates would reduce grout shipping cost, and consequently its final cost. Furthermore, the utilization of recycled aggregates would permit the reuse of waste materials that nowadays are carried to landfill, reducing its final environmental impact.

In this paper silica sand $(S)$ is used as reference aggregate since it is the one most used nowadays. Limestone sand $(L)$ is studied as an alternative natural aggregate, widely used in Spain for making structural concrete. Electric arc furnace slag (EAF) represents the recycled aggregates that are used at the present for other purposes such as making concrete, asphalt concrete, or directly used as sub-base or landfill in road construction. Finally, the construction and demolition waste (CDW) represents the waste aggregates that are discarded nowadays (this paper uses a $2 \mathrm{~mm}$ maximum aggregate size, whose use is not permitted in the actual Spanish structural concrete standard (EHE08)). Properties of the aggregates used are summarized in Table 2.

Table 3 shows the mix proportions used in the freeze-thaw analysis. Finally, water content of the mix proportions have been determined to meet the $260-300 \mathrm{~mm}$ diameter of the flow table consistency test (UNE-EN 1015-3 [13]).

Table 2. Aggregate properties [12]

\begin{tabular}{|c|c|c|c|c|c|c|}
\hline & & & \multicolumn{2}{|c|}{ EAF* $^{*}$} & \multicolumn{2}{|c|}{$\mathrm{CDW}^{* *}$} \\
\hline & & & EAF & $\mathbf{F}$ & CDW & $\mathbf{F}$ \\
\hline Specific gravity & & 2.65 & 3.82 & 2.753 & 2.57 & 2.753 \\
\hline Water absorption (\%) & 0.52 & 0.16 & 1.83 & N/A & 5.07 & $\mathrm{~N} / \mathrm{A}$ \\
\hline Sieve $(\mathrm{mm})$ & \multicolumn{6}{|c|}{ Passing percentage by volume } \\
\hline 4 & 100.0 & 100.0 & \multicolumn{2}{|c|}{100.0} & \multicolumn{2}{|c|}{100.0} \\
\hline & 99.3 & 100.0 & \multicolumn{2}{|c|}{99.9} & \multicolumn{2}{|c|}{100.0} \\
\hline & 61.3 & 78.6 & \multicolumn{2}{|c|}{57.4} & \multicolumn{2}{|c|}{75.7} \\
\hline 0.5 & 40.1 & 65.6 & \multicolumn{2}{|c|}{37.6} & \multicolumn{2}{|c|}{52.1} \\
\hline 0.25 & 27.7 & 46.9 & \multicolumn{2}{|c|}{32.5} & \multicolumn{2}{|c|}{35.1} \\
\hline 0.125 & 20.5 & 27.2 & \multicolumn{2}{|c|}{28.5} & \multicolumn{2}{|c|}{24.7} \\
\hline 0.063 & 15.7 & 17.5 & \multicolumn{2}{|c|}{23.5} & \multicolumn{2}{|c|}{17.6} \\
\hline
\end{tabular}

*EAF $75 \%$ and Limestone Filler (F) $25 \%$ by weight

**CDW $90 \%$ and $\mathrm{F} 10 \%$ by weight 
Table 3. Mix proportions of the cement based grouting materials used

\begin{tabular}{lccccc}
\hline & \multicolumn{5}{c}{ Grouting material } \\
\cline { 2 - 6 } & N & L & S & EAF & CDW \\
\hline Cement (c) & & \multicolumn{4}{c}{ CEM II/B(V) $32.5 R$} \\
Aggregate 1 (A1) & - & L & S & EAF & CDW \\
A1/c & - & 2 & 2 & 1.5 & 1.80 \\
Aggregate 2 (A2) & - & - & - & $F$ & $\mathrm{~F}$ \\
A2/c & - & 0 & 0 & 0.5 & 0.20 \\
Superplasticizer (SP) & & & Melment F10 & \\
SP/c & 0.02 & 0.02 & 0.02 & 0.02 & 0.02 \\
Water to cement ratio (w/c) & 0.3 & 0.39 & 0.43 & 0.42 & 0.66 \\
\hline
\end{tabular}

\subsection{Mortar characterization}

For the physical characterization of the mortars, volumetric water content of the hardened mortar was determined based on the UNE-EN 1015-10 standard [14] (1). Results were obtained as the mean of the 3 specimens tested. This method has been successfully used to determine the volumetric water content by other authors [15].

$$
\phi_{w}=\frac{\left(m_{\text {sat }}-m_{\text {dry }}\right)}{\left(m_{\text {sat }}-m_{\text {sub }}\right)}
$$

Where,

- $\quad \boldsymbol{\phi}_{\mathrm{w}}$ is the volumetric water content (-)

- $\quad \mathbf{m}_{\text {sat }}$ is the water-saturated mass of the specimen $(\mathrm{kg})$

- $\quad \mathbf{m}_{\text {sub }}$ is the water-submerged mass of the specimen $(\mathrm{kg})$

- $\quad \mathbf{m}_{\text {dry }}$ is the oven dried mass of the specimen $(\mathrm{kg})$

Mechanical properties of the hardened mortar matrix were determined by the flexural and compressive loads according to UNE-EN 1015-11 [16]. Specimens were oven dried for $24 \mathrm{~h}$ at 105ㅇ $\mathrm{C}$ and tested at $20^{\circ} \mathrm{C}$ once they reached thermal equilibrium. Flexural load was determined as the mean of the three specimens tested, while compressive load was determined as the mean of the six specimens tested. To complete the mechanical characterization of the mortars, a non-standardized test was performed to determine the pipe to mortar bond strength. The test is based on the push out test proposed by Allan et al. $[17,18]$. Fig 1shows a sketch of the test, as well as one of the specimens tested. Mortar specimen was $110 \mathrm{~mm}$ diameter and $124 \mathrm{~mm}$ high hollow cylinder. Centered along the axis of the cylinder, a PE100/SDR11 embedded 32mm diameter high density polyethylene pipe was placed. To allow the pipe going downward because of the applied load, a $40 \mathrm{~mm}$ diameter and $19 \mathrm{~mm}$ high cylindrical gap was left at the bottom surface of the mortar specimen. During the test, a uniform vertical load was applied on the top annular surface of the pipe to push it out of the specimen. A constant load increment of $25 \mathrm{~N} / \mathrm{s}$ was set and the maximum displacement was limited to $5 \mathrm{~mm}$ for safety reasons. As the tests were performed immediately after the removal of the probes from the water, tests were carried out at 15으. The resulting load-displacement curves presented a sharp load decrease once the pipe began to slide through the grout before the maximum displacement was reached. The pipe to mortar bond strength $\left(F_{b}\right)$ was determined as the maximum load registered during the test. Final test result is obtained as the mean value of three specimens tested.

Finally, apparent thermal conductivity of the water-saturated hardened mortar was determined according to the ASTM D-5334 [19] standard. Mortar specimens were $16 \mathrm{~cm}$ diameter and $20 \mathrm{~cm}$ high cylinders. When mortar was still fresh, a $1.7 \mathrm{~mm}$ inner-diameter and $17 \mathrm{~cm}$ long hollow stainless steel pipe was introduced 
axially centered to permit the later insertion of the testing needle. During the 300 s testing period, the needle probe injected a constant $45 \mathrm{~W} / \mathrm{m}$ heating power $(\mathrm{Q})$, recording its temperature rise $(\Delta T)$. According to the infinite line source theory [20] and based on the results obtained, apparent thermal conductivity of the mortar $(\lambda)$ was determined with the equation $(2) . H$ is the thermal needle heating length $(0.1 \mathrm{~m})$ and $s$ is the slope of $\Delta T$ with the Napierian logarithm of time, which is calculated by a least squares fitting of the 35270s time interval. Three tests were performed per specimen, and the resulting thermal conductivity was determined as the mean value of the three specimens performed per cycle time.

$$
\lambda=\frac{Q}{4 \cdot \pi \cdot H \cdot s}
$$

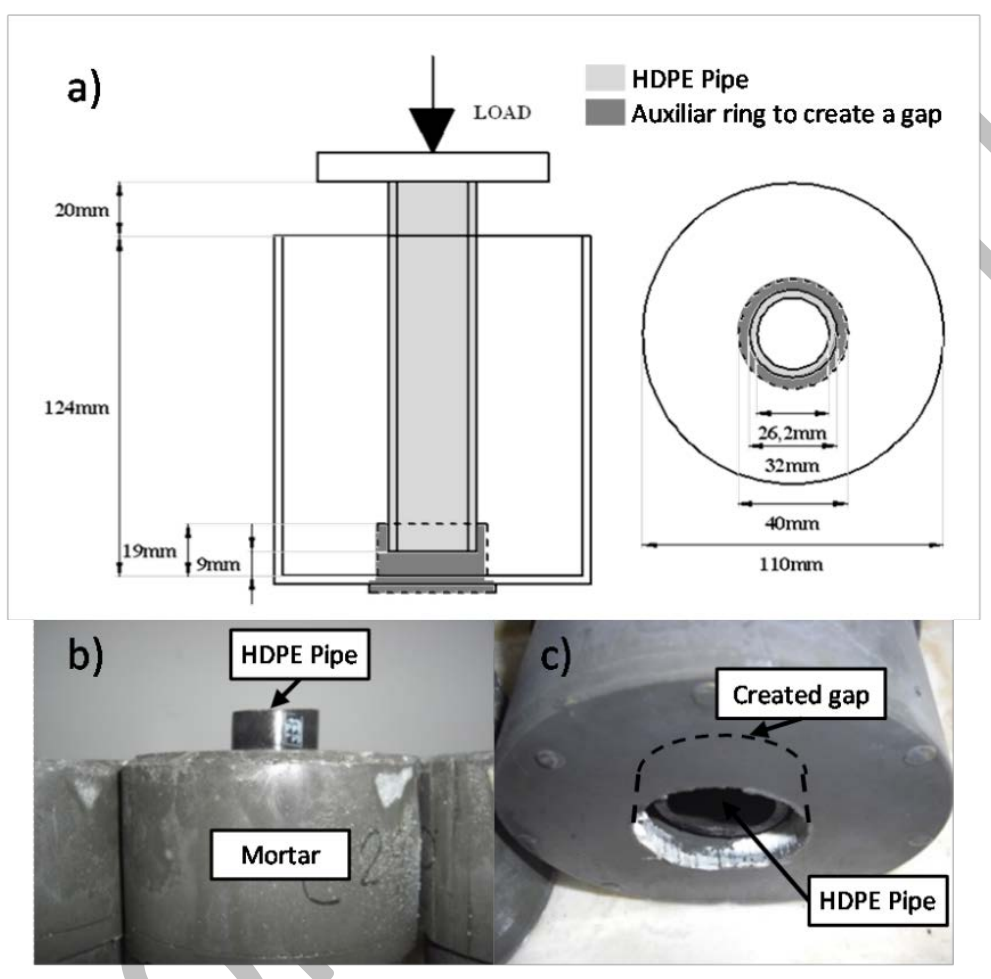

Fig. 1. Adherence probe: a) Geometry of the probe (b) detail of pipe top where the load is applied and c) cylindrical gap created to allow the pipe going downward.

All the specimens where cured under ambient laboratory conditions for $24 \mathrm{~h}$ after making the mix. Once molds were removed, all the specimens were cured submerged into water at $20 \circ \mathrm{C}$ for another 28 days to reach initial conditions before the beginning of any treatment. Then, one half of the specimens were subject to freeze-thaw (FT) cycles. For every cycle, specimens were frozen water-saturated at $-17^{\circ} \mathrm{C}$ for $24 \mathrm{~h}$ and submerged into water at $15 \circ \mathrm{C}$ for other $24 \mathrm{~h}$. At the same time, the other half of the specimens were cured permanently submerged into water at $15^{\circ} \mathrm{C}$ to also quantify the influence of the curing age in the evaluated properties. Mortar properties were determined at 0, 7, 14 and 25 freeze-thaw cycles. In parallel, same tests were performed in the probes submerged into water.

\section{RESULTS AND DISCUSSION}

\subsection{Volumetric water content of the hardened mortar}

Fig. 2 shows the initial and final volumetric water content of the different mortars subject to continuous water submersion or subject to 25 freeze-thaw cycles. According to the results obtained, it was evident that aggregate type had a bigger influence than both of the treatments analyzed. At first sight, the evolution of the water content for each treatment was different depending on the type of mortar evaluated. For all the 
mortars there existed a reduction of the volumetric water content with the continuous water-submerged curing, as predicted by Tekin et al. [21], who observed that porosity of the cementitious materials was reduced with the curing age. Accordingly, Allan et al. [18] also observed a reduction of the water infiltration capacity with the curing age. However, the water content of the probes subject to freeze-thaw cycles was not reduced as much as that of the probes subject to water submerged curing. For the $N, C D W$ and $S$ mortars the water content even increases. During the freeze-thaw cycles, probes were submerged into water and frozen at air, alternating the pressure and temperature conditions on the probe surface and enhancing the water infiltration capacity of the mortar.

This phenomenon is more likely to occur near the ground surface, where the grout is exposed to unsaturated conditions and to the alternation of cold and wet cycles during the winter due to the heating demand, ambient air temperature variation and water-table variation. For the grout below water-table, pressure and exposition to water could be considered constant, and the temperature variation also will be less than the one observed in the upper part due to the higher thermal conductivity and heat capacity of the ground and grout enhanced by the constant water presence. Therefore, the volumetric water content of the grout could be higher in the non-saturated zone than the one immediately under the water table.

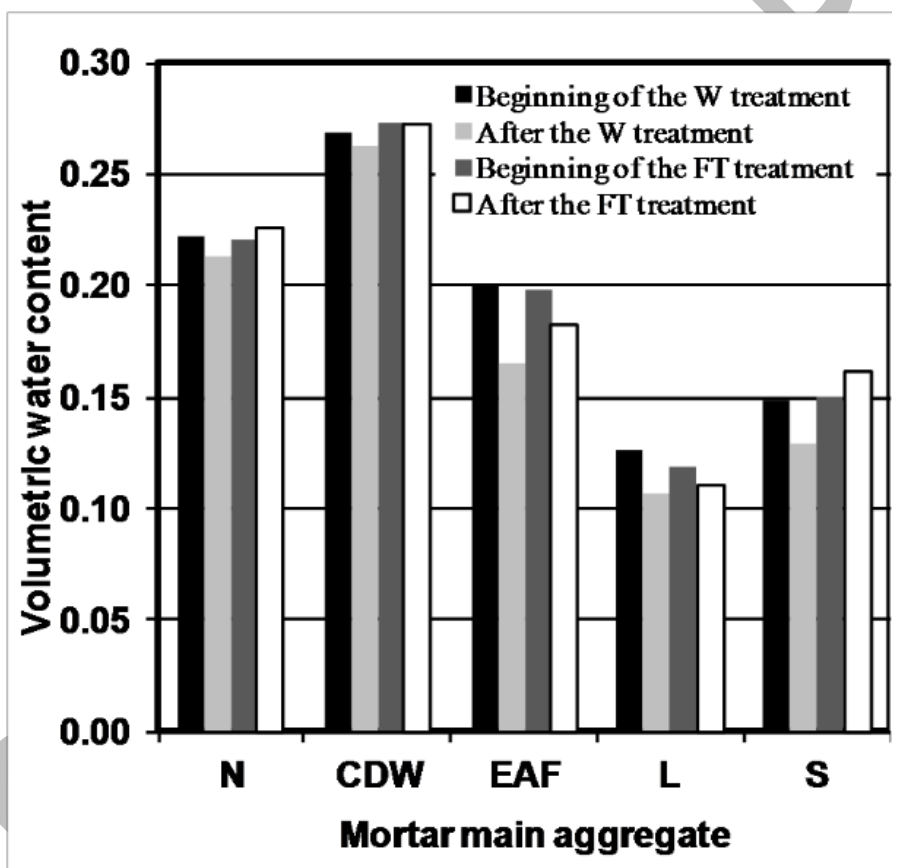

Fig. 2. Influence of the aggregate type, freeze thaw cycles (FT) and continuous water curing (W) on the volumetric water content of the mortars.

Once determined the significant importance of the aggregate type on the volumetric water content of the resulting mortar, the origin of the water content was analyzed. Fig.3 shows the influence of the water to cement ratio used in the mix and all the determined volumetric contents for each of the mortars studied. It was evident that the water content of the hardened mortar came from the water used during its fabrication. For the mortars containing any aggregate and with a similar consistency this relationship was linear and depended on the water absorption of the main aggregate used. However, for the neat cement mix, the lower than expected water content could be attributed to the absence of aggregate and its inherent water absorption capacity. For all the cases evaluated, volumetric water content was smaller than the water dosage used for mortar mixing, denoting that part of the water did not react with the cement and remained in the mortar pore structure. This relation also indicated that the core of the probes was not saturated. 


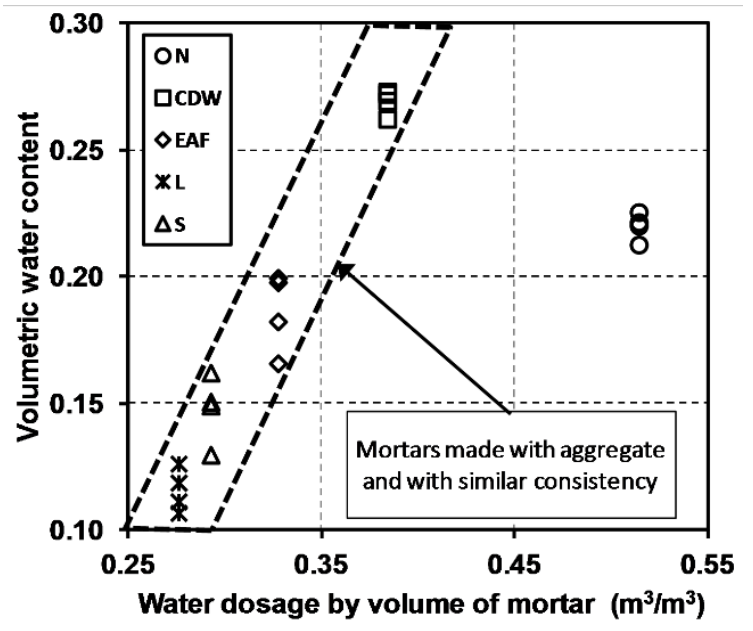

Fig 3. Influence of the water dosage used in the mix on the resulting volumetric water content.

\subsection{Mechanical properties of the hardened mortar}

At first, all the evaluated probes were treated as the same sample, without taking into consideration either the aggregate type or treatment applied. Fig. 4 shows the influence of the volumetric water content on the flexural, compressive and adherence loads.

a)

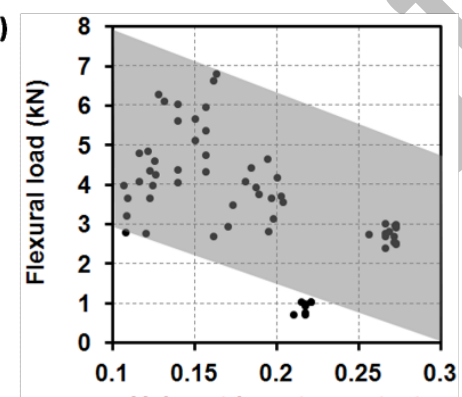

b) 140 Volumetric water content
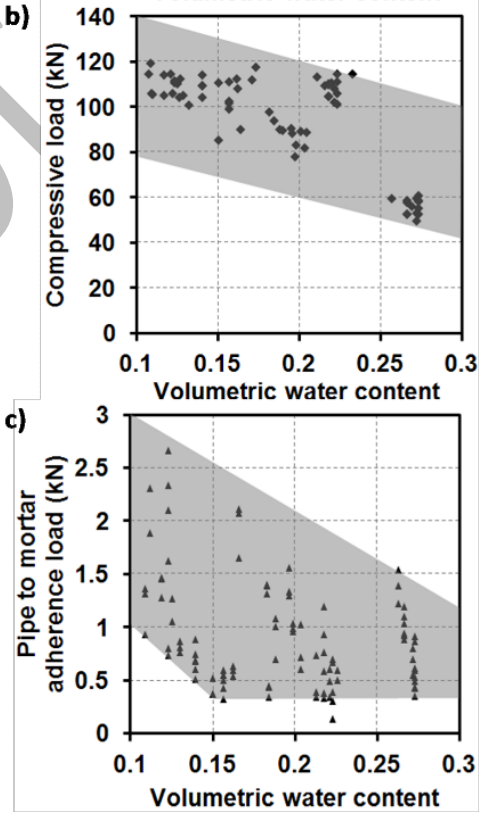

Fig. 4. Influence of the volumetric water content on the mechanical behavior of the evaluated mortars a) Flexural load b) compressive load and c) pipe to mortar adherence load.

As volumetric water content increased, a decrease of the flexural and compressive strength was observed, as predicted by Chen et al. [15]. However, in this case the relation was more dispersed since the different volumetric water content of the mixes was obtained by changing the aggregate type, not the water to 
cement ratio of the mix. Pipe to mortar adherence seemed to present a similar trend for maximum loads with similar volumetric water content while minimum loads seemed to be independent. No relation was found between the internal mechanical properties of the mortar - flexural and compressive loads - and the pipe to mortar adherence load. Therefore, pipe to mortar adherence seemed to depend only on their contact surface conditions. For the maximum loads, it looked like water acted as a lubricant in the contact surface reducing the pipe to mortar adherence. However, the minimum loads seemed to be independent of the volumetric water content, which indicated that the pipe to mortar adherence failed due to imperfections of the contact surface before the water-lubrication effect appeared.

The damage caused by the probes subject to water submerged curing and freeze-thaw cycles on each mortar were analyzed separately. Fig. 5 shows the evolution of the flexural, compressive and adherence loads with the treatment duration for all the mortars evaluated.

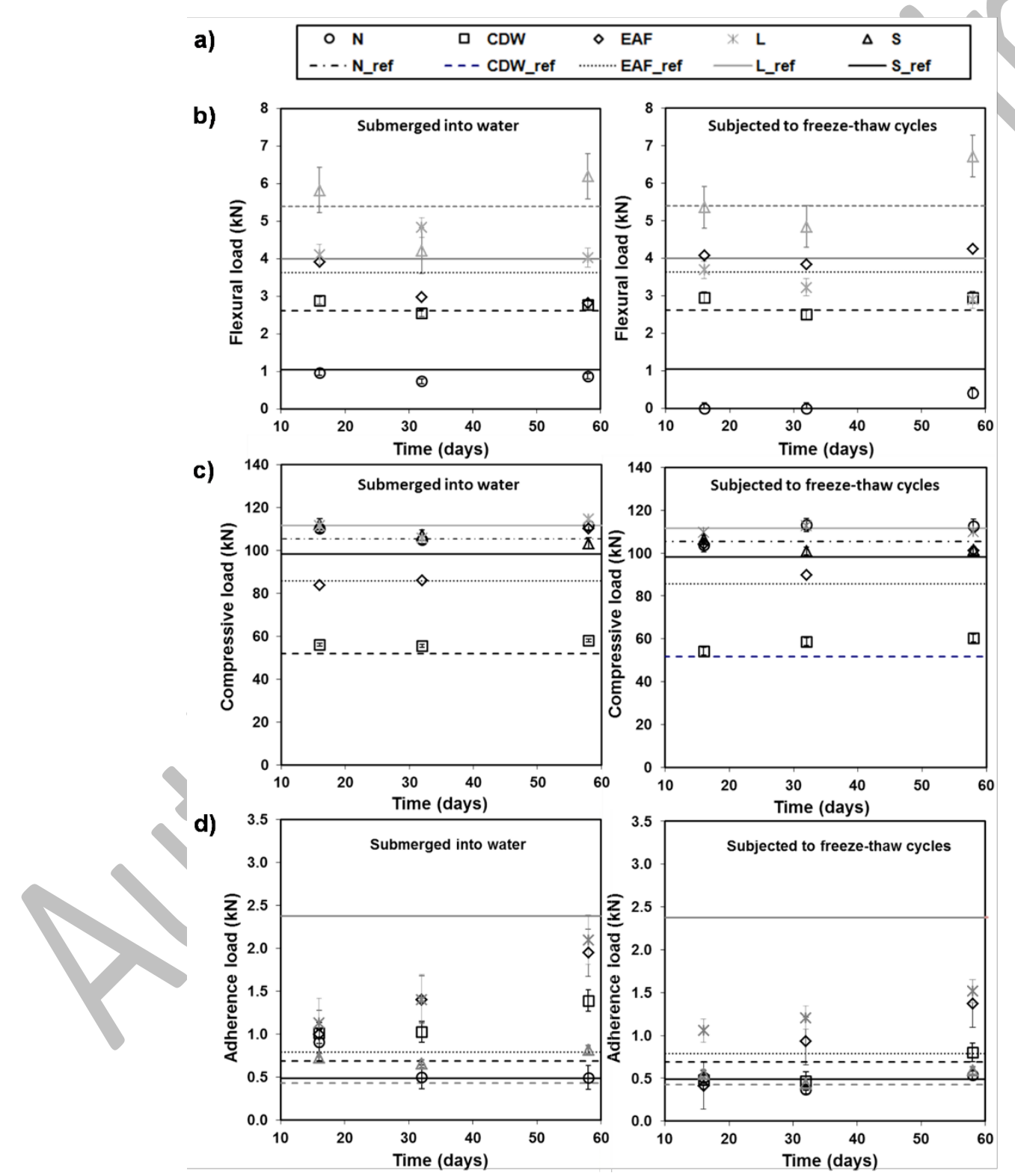

Fig. 5. Evolution of the mechanical strength with the treatment type and time applied: a) symbol statement and b) flexural, c) compressive and d) adherence loads.

Horizontal lines represent the reference values measured prior to the beginning of the treatments, just after the 28 days curing period was concluded. All the mortars but the neat cement presented no influence of any treatment on the flexural and compressive strengths, probably due to the non-saturation of the 
probes [22]. For the adherence load, the $\mathrm{N}$ and $\mathrm{S}$ mortars followed a similar trend; however, the CDW, EAF and $L$ mortars seemed to present an increase of the adherence load for both treatments, which was of less importance for the probes subject to freeze-thaw cycles, denoting a small damage due to the treatment applied (the higher initial value observed for the $L$ mortar was attributed to the higher temperature registered by error during the test, as indicated by Allan et al. [18]). To verify if the mechanical strength of the materials was affected by any of the treatments applied, probability-probability plots of flexural, compressive and adherence loads were determined for each mortar, without any treatment distinction (Fig 6). For the flexural and compressive loads it was observed that all the mortars fit a normal distribution, indicating that the variations of the results were due to the uncertainty of the test procedure. According to the adherence load, as the vertical load applied to the pipe increases, the micro-cracks in the pipe to mortar contact surface increased until a minimum energy condition was reached to debond the pipe from the mortar. Therefore, the adherence load was the result of an accumulated damage in the pipe to mortar contact surface and behaved following a Weibull distribution, as proved by other authors for other materials [23-26]. As the example of the CDW mortar shown in Fig. 6, adherence load for all the mortars fit to a Weibull distribution, indicating that the slight improvement observed for the adherence load could be also due to the testing procedure. As a conclusion, for all the mortars analyzed but the neat cement, the mechanical properties of the mortars evaluated were not affected by either the water curing or freezethaw cycles.
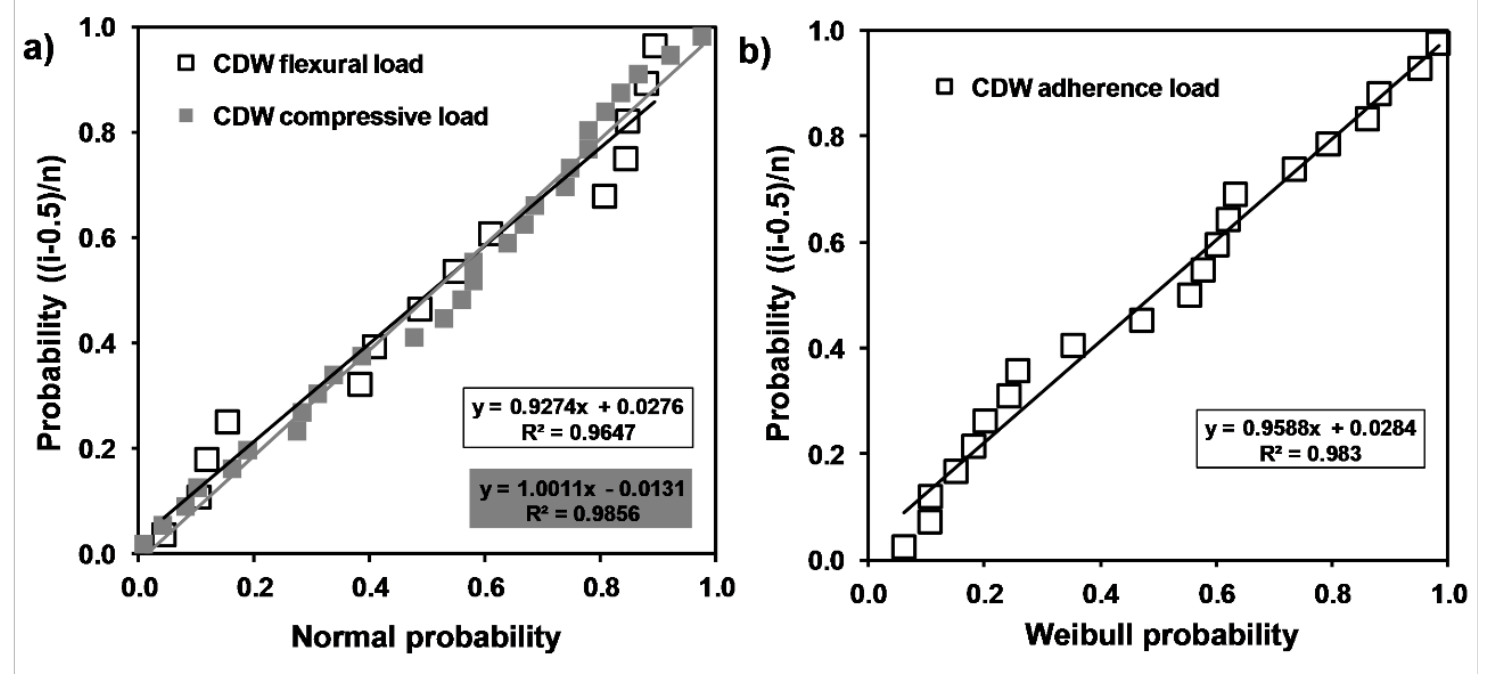

Fig. 6. Probability-Probability plots of the mechanical strength for the CDW mortar: a) flexural and compressive loads and b) adherence load.

On the contrary, for the neat cement mortar, severe damage was observed in all flexural probes and in two of the nine adherence probes subject to freeze-thaw treatment. All the flexural probes were broken in two halves prior to the realization of the first set of flexural tests ( 7 cycles); hence, the freeze-thaw strength of the neat cement mortar was considered negligible. However, its appearance and the compressive load of the resulting two halves were similar to that of the probes submerged into water, denoting that the damage was only local. Accordingly, two adherence probes broke after 4 and 7 freeze-thaw cycles, just after the introduction of the probes into water. Both probes presented only one failure surface, as it is shown in Fig 7. When adherence probes were introduced into the water bath at $15 \circ \mathrm{C}$, a temperature gradient was created between the embedded pipe and the mortar to pipe contact surface. As the thermal expansion coefficient of the HDPE is higher than that of the mortar [2], the pipe created a tangential tension in the mortar, causing the failure in the imperfection shown in Fig. 7 and propagating it until the overall failure. 


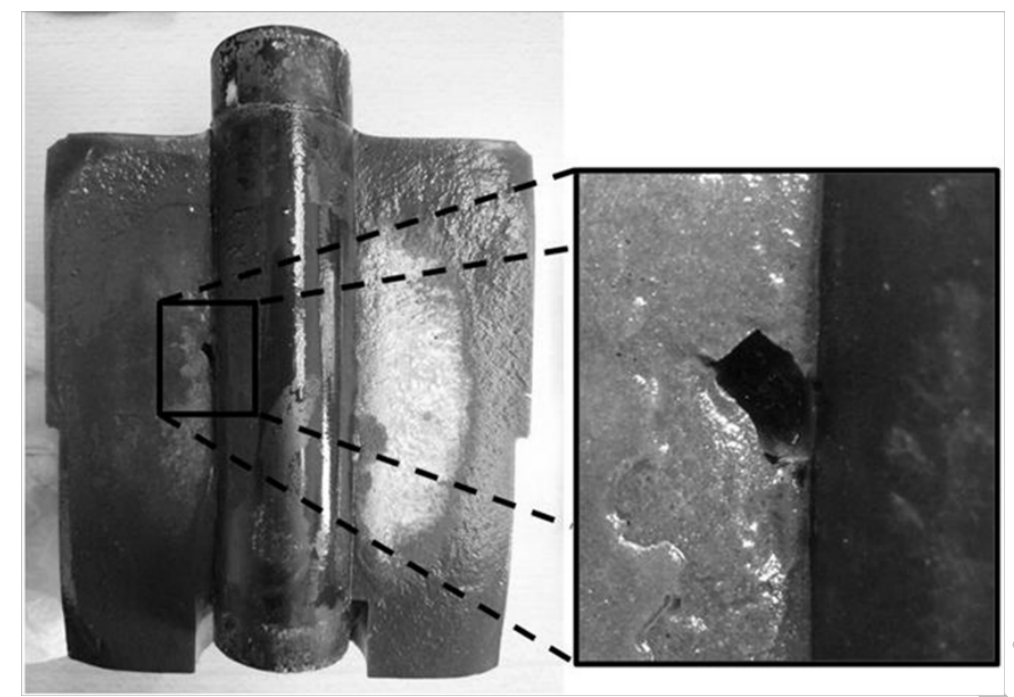

Fig 7. Failure observed in the two adherence probes due to the freeze-thaw cycles.

\subsection{Thermal conductivity of the hardened mortars}

As for the mechanical properties, at first all the mortars were treated as part of the same sample to analyze the influence of the water content on the thermal conductivity of the mortars. As shown in Fig. 8, the influence of the aggregate type was more relevant than the one of the water content. Therefore, each mortar was evaluated separately to determine the possible influence of the type of exposition on the thermal conductivity of the mortars.

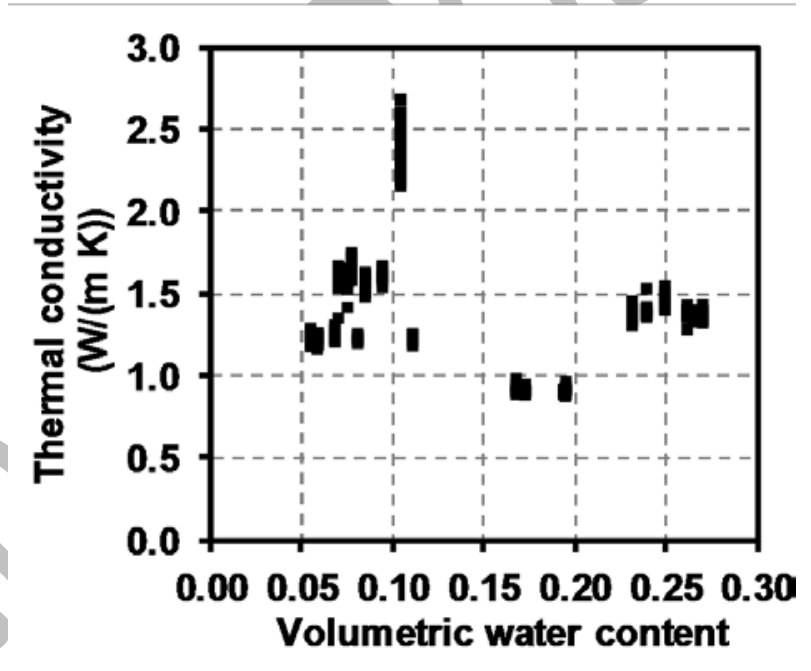

Fig. 8 Influence of the water content on the thermal conductivity of the resulting mortar.

Fig. 9 shows the time dependence of the thermal conductivity for the different mortars and expositions analyzed. As for the mechanical properties, no time dependence was observed for any of the mortars, as it was later confirmed by their probability- lognormal probability plot shown in Fig. 10. Thermal conductivity probes of the neat cement mortar presented a severe damage (Fig. 11). However, damage did not alter the resulting thermal conductivity. Therefore, it seems that thermal conductivity of the mortar matrix would remain undisturbed and that any increment of the borehole thermal resistance of a vertical heat exchanger must be caused because of the appearance of surface contact resistances between the pipe and mortar or at mortar failure plains. 

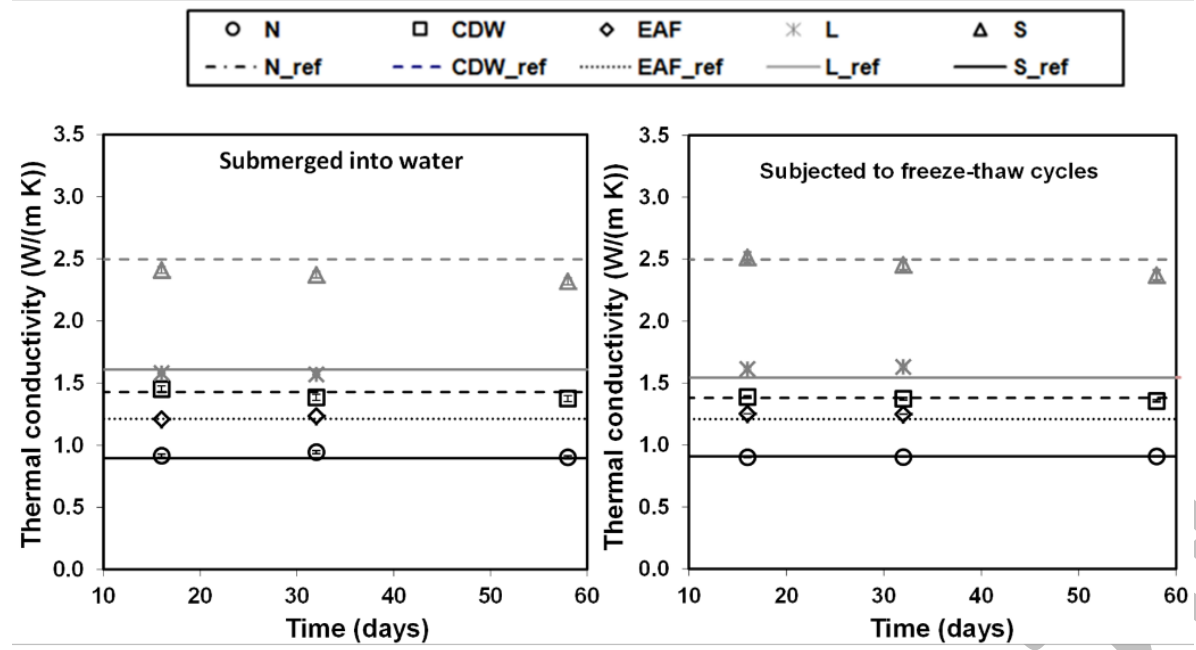

Fig. 9. Evolution of the thermal conductivity with the treatment type and time applied

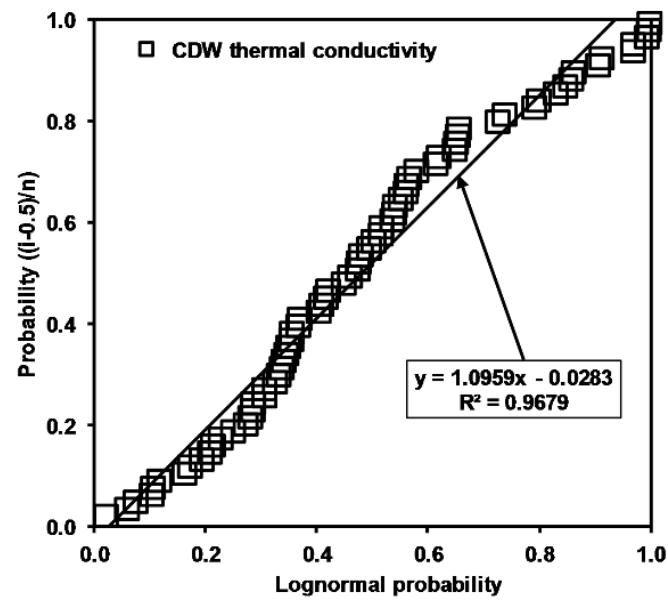

Fig. 10. Probability-Probability plots of the thermal conductivity for the CDW mortar.

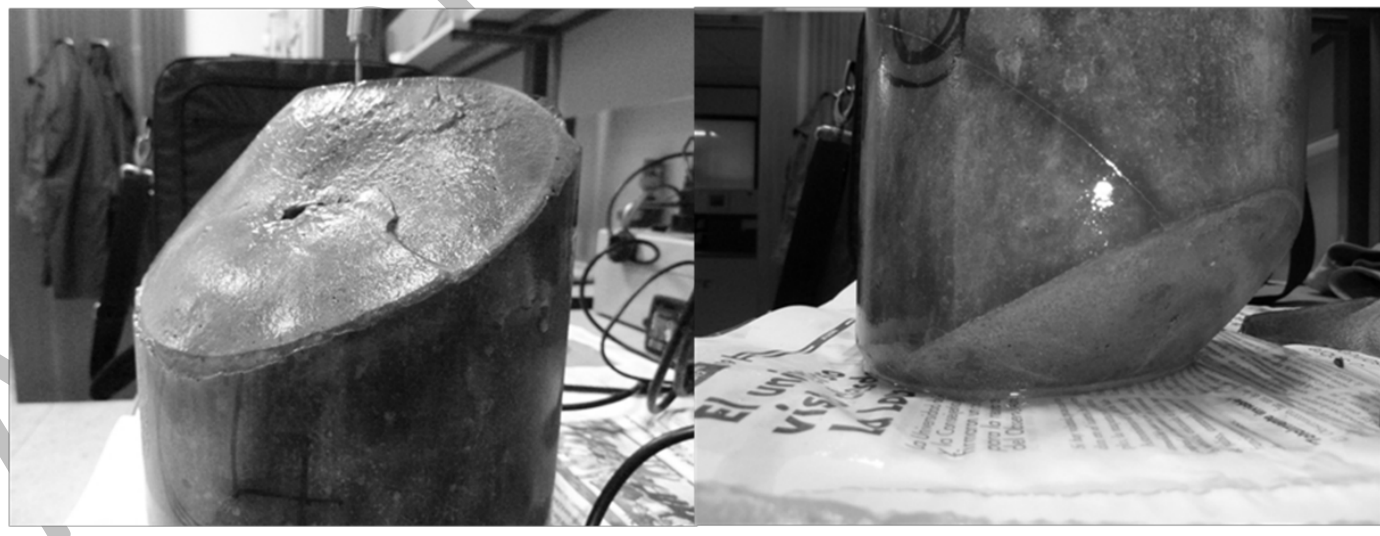

Fig. 11. Failure observed in the thermal conductivity probes of the Neat cement mortar

\section{CONCLUSIONS}

Freeze-thaw durability of five different geothermal cement-based grouting mortars has been examined to analyze the possibility of overloading a geothermal heat exchanger system to cover the building heating peak demand. For that purpose, evolution of water content, mechanical properties and thermal conductivity of different mortars containing either limestone sand (L), silica sand (S), electric arc furnace 
slag (EAF) or construction and demolition waste (CDW) were compared with a reference neat cement mortar. Thus, the goals proposed in this paper have led to the following conclusions:

- The aggregate type used has a bigger influence than the applied freeze-thaw cycles on both the water content and thermal conductivity of the resulting mortars. Water content presents a linear dependence with the water proportion used in the mix, indicating that the probe core was not saturated.

- According to the proposed freeze-thaw cycles, no significant damage has been observed on the mechanical and thermal properties of the mortars containing any of the aggregates proposed, probably due to the non saturation of the probe core.

- Freeze-thaw cycles applied on the neat cement grout caused a severe impact on the flexural, adherence and thermal conductivity probes. However, damage did not vary its thermal conductivity, indicating that any thermal conductivity loss produced in the grout must be due to the appearance of thermal contact resistances at the failure planes caused by the freeze-thaw damage.

\section{ACKNOWLEDGEMENTS}

The authors wish to acknowledge the support provided by the GITECO Research Group of Construction Technology and Highways Research Group (GCS) of the University of Cantabria and the Department of Construction at the University of Oviedo. The authors wish to express their gratitude to the Spanish Ministry of Economy and Competitiveness which funded this study through the research project BIA200908272. Finally, authors wish to acknowledge the financial support provided by the research projects FICYT FC-10-EQUIP10-17 and BIA-2008-00058.

\section{BIBLIOGRAPHY}

[1] EPA. US Environmental Protection Agency. Energy Star Program. http://www.energystar.gov.

[2] Holman JP. Heat transfer (Spanish:"Transferencia de calor"). 8th ed. Madrid: Mc Graw hill, 1999.

[3] Allan ML, Philippacopoulos AJ. Properties and Performance of Cement-Based Grouts for Geothermal Heat Pump Applications. Final Report 1999.

[4] Park M, Min S, Lim J, Choi JM, Choi H. Applicability of cement-based grout for ground heat exchanger considering heating-cooling cycles. Sci China Technol Sci 2011;54:1661-7.

[5] Qiao P, Xu Y. Effects of Freeze-thaw and Dry-wet Conditionings on the Mode-I Fracture of FRP-concrete Interface Bonds. Eng Constr Oper Challeng Environ Earth Space Proc 9th Biennial ASCE Aerosp Div Internat Conf 2004:601-8.

[6] Colombi P, Fava G, Poggi C. Bond strength of CFRP-concrete elements under freeze-thaw cycles. Compos Struct 2010;92:973-83.

[7] Green MF, Bisby LA, Beaudoin Y, Labossière P. Effect of freeze-thaw cycles on the bond durability between fibre reinforced polymer plate reinforcement and concrete. Can J Civ Eng 2000;27:949-59.

[8] Hanjari KZ, Utgenannt P, Lundgren K. Experimental study of the material and bond properties of frostdamaged concrete. Cem Concr Res 2011;41:244-54.

[9] Manso JM, Polanco JA, Losañez M, González JJ. Durability of concrete made with EAF slag as aggregate. Cem Concr Compos 2006;28:528-34.

[10] Maurenbrecher A, Suter G, Trischuk K, Fontaine L. Contribution to pointing mortar durability. 2010:361-9. 
[11] Cao JY, Chung DDL. Damage evolution during freeze-thaw cycling of cement mortar, studied by electrical resistivity measurement. Cem Concr Res 2002;32:1657-61.

[12] Borinaga-Treviño R, Pascual-Muñoz P, Castro-Fresno D, Del Coz-Díaz JJ. Study of different grouting materials used in vertical geothermal closed loop heat exchangers. Applied Thermal Engineering 2012;50 (1):159-67.

[13] UNE-EN 1015-3. Methods of test for mortar for masonry. Part 3: Determination of consistence of fresh mortar (by flow table). 2006.

[14] UNE-EN 1015-10. Methods of test for mortar masonry. Part 10: Determination of dry bulk density of hardened mortar. 2007.

[15] Chen X, Wu S, Zhou J. Influence of porosity on compressive and tensile strength of cement mortar. Constr Build Mater 2013;40:869-74.

[16] UNE-EN 1015-11. Methods of test for mortar for masonry. Part 11: Determination of flexural and compressive strength of hardened mortar. 2007.

[17] Allan M. Thermal Conductivity of Cementitious Grouts for Geothermal Heat Pumps: FY 1997 Progress Report. BNL 1997;65:129.

[18] Allan ML. Materials characterization of superplasticized cement-sand grout. Cem Concr Res 2000;30:937-42.

[19] ASTM D-5334-08. Standard test method for Determination of thermal conductivity of soil and soft rock by thermal needle procedure. 2008.

[20] Mogensen P. Fluid to duct wall heat transfer in duct heat storages. Proceedings of the international conference on subsurface heat storage in theory and practice. Swedish Council for Building Research 1983:652-7.

[21] Tekin I, Birgul R, Aruntas HY. Determination of the effect of volcanic pumice replacement on macro void development for blended cement mortars by computerized tomography. Constr Build Mater 2012;35:15-22.

[22] ASTM C666/C666M-03: Standard Test Method for Resistance of Concrete to Rapid Freezing and Thawing. 2003.

[23] Hobson RS, McCabe JF, Hogg SD. Bond strength to surface enamel for different tooth types. Dent Mater 2001;17:184-9.

[24] Burrow MF, Thomas D, Swain MV, Tyas MJ. Analysis of tensile bond strengths using Weibull statistics. Biomaterials 2004;25:5031-5.

[25] Hartig J, Jesse F, Schicktanz K, Häußler-Combe U. Influence of experimental setups on the apparent uniaxial tensile load-bearing capacity of Textile Reinforced Concrete specimens. Mater Struct 2012;45:43346.

[26] García A, Norambuena-Contreras J, Partl M. A parametric study on the influence of steel wool fibers in dense asphalt concrete. Materials and Structures 2013;DOI: . 10.1617/s11527-013-0135-0 